\title{
Current evidence for the hepatoprotective activities of the medicinal mushroom Antrodia cinnamomea
}

\author{
Patrick Ying-Kit Yue ${ }^{1 *}$, Yi-Yi Wong ${ }^{1}$, Kay Yuen-Ki Wong ${ }^{1}$, Yeuk-Ki Tsoi ${ }^{2}$ and Kelvin Sze-Yin Leung ${ }^{2 *}$
}

\begin{abstract}
Antrodia cinnamomea (AC) is an endemic mushroom species of Taiwan, and has been demonstrated to possess diverse biological and pharmacological activities, such as anti-hypertension, anti-hyperlipidemia, anti-inflammation, anti-oxidation, anti-tumor, and immunomodulation. This review focuses on the inhibitory effects of AC on hepatitis, hepatocarcinoma, and alcohol-induced liver diseases (e.g., fatty liver, fibrosis). The relevant biochemical and molecular mechanisms are addressed. Overall, this review summarizes the hepatoprotective activities in vitro and in vivo. However, there is no doubt that human and clinical trials are still limited, and further studies are required for the development of AC-related products.
\end{abstract}

\section{Introduction}

Antrodia cinnamomea (AC) (niu-chang-chih in Chinese) is a medicinal mushroom (Figure 1) endemic to Taiwan. It has been well-known for its medicinal properties, particularly with regard to liver complaints [1], since its first identification as a new species by Zang and $\mathrm{Su}$ in 1990 [2]. Among its diverse pharmacological activities, the evidence for hepatic protection is the most recognized and the strongest. Studies have shown that AC can inhibit hepatic tumor growth and retard the progression of hepatitis [3,4]. Although AC is currently used as a food supplement, the Food and Drug Administration (FDA) has not approved any AC extracts or purified compounds for clinical applications. Some AC products are claimed to protect the liver against food and drug intoxication, especially alcohol-induced liver damage, maintain hepatic homeostasis, or both. This article reviews the current evidence for the hepatoprotective properties (such as effects on hepatitis, cirrhosis, liver cancers, and alcoholic damage) of AC extracts and active compounds.

\footnotetext{
* Correspondence: patrick@hkbu.edu.hk; s9362284@hkbu.edu.hk 'Department of Biology, Faculty of Science, Hong Kong Baptist University, Hong Kong, SAR, China

2Department of Chemistry, Faculty of Science, Hong Kong Baptist University, Kowloon, Hong Kong SAR, China
}

\section{Effects on hepatitis}

\section{General background of hepatitis}

Hepatitis is one of the top ten causes of death worldwide (more than one million deaths per year), and is mainly classified into hepatitis $\mathrm{A}, \mathrm{B}$, and $\mathrm{C}$, involving different types of viruses, epigenetic and genetic alterations, pathological progressions, and clinical treatments [5]. Hepatitis $\mathrm{A}$ is an acute infectious liver disease caused by hepatitis $\mathrm{A}$ virus (HAV). It is transmitted by a fecal-to-oral route, and mainly occurs as outbreaks from fecal contamination of food or water sources or direct contact with carriers. It has no clinical signs or symptoms in most infected people, and most cases recover within 1-2 months [6]. Hepatitis A causes the least problems among the various types of hepatitis, and its incidence rate has been diminishing in recent years, probably through improved hygiene [6]. Hepatitis $B$ and $C$ are acute and chronic infections caused by hepatitis $B$ virus (HBV) and hepatitis $\mathrm{C}$ virus (HCV), respectively, and are more serious. $\mathrm{HBV}$ and $\mathrm{HCV}$ belong to the Hepadnaviridae and Flaviviridae, respectively. HBV is a DNA virus that can integrate into the host genome after infection, while $\mathrm{HCV}$ is an RNA virus that has no such ability [6]. According to a worldwide epidemiological evaluation, at least 400 and 170 million people are chronically infected with $\mathrm{HBV}$ and $\mathrm{HCV}$, respectively $[7,8]$. In fact, these viruses persist in the liver in about $80 \%$ of infected people [9], and such chronic viral infections may be 


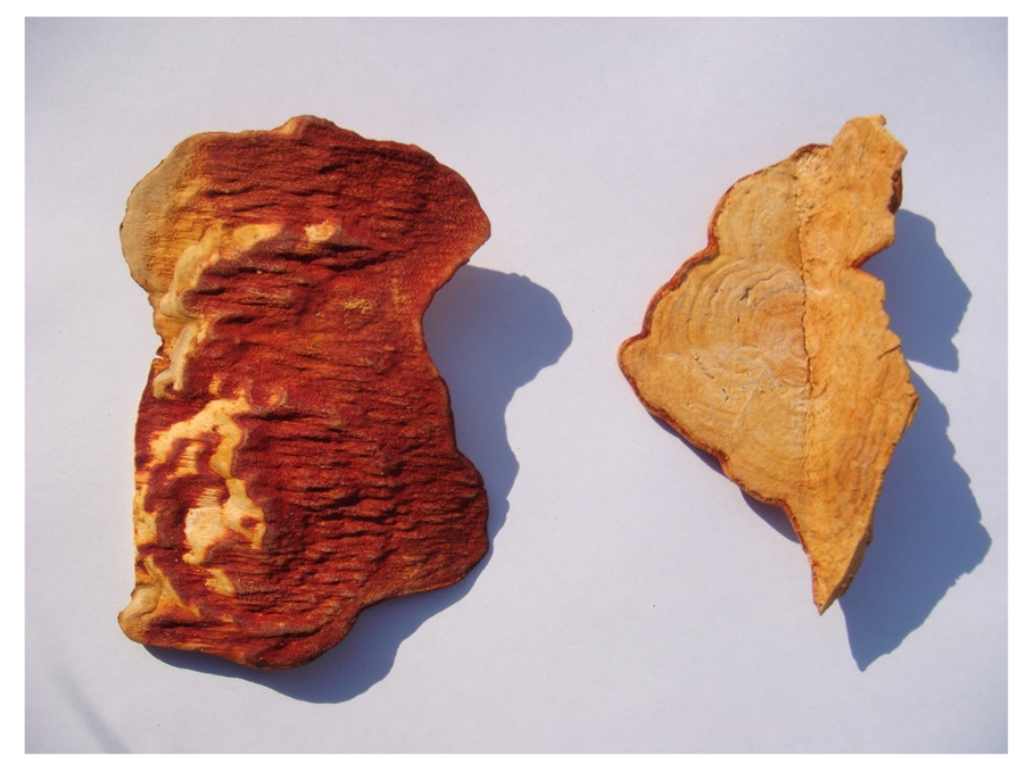

Figure 1 Morphological appearance of Antrodia cinnamomea.

associated with chronic inflammation that leads to scarring of the liver tissues and cirrhosis [10]. Upon infection, HBV and HCV interact with host hepatocytes, impair cell metabolism (e.g., induce cell death) [11], modulate signaling pathways of protein synthesis (e.g., produce viral proteins and enzymes) $[12,13]$ and immunity (e.g., synthesize and place viral antigens on host cell surfaces) [14], and develop immortalization (e.g., modulate surface markers). Ultimately, $1-5 \%$ of cirrhotic livers develop hepatocellular carcinoma (HCC) [15].

\section{Anti-hepatitis activity}

Inhibition of viral proteases, which are crucial for viral replication, can interrupt viral protein maturation. Antrodins (A to E) and their metabolic analogues selectively inhibited HCV NS3/4A protease activity [3]. Among these, antrodin A (the major in vivo metabolite of antrodin $\mathrm{C}$ ) showed the highest potency with an $\mathrm{IC}_{50}$ of $0.9 \mu \mathrm{g} / \mathrm{mL}$, while antrodin B showed lower potency with an $\mathrm{IC}_{50}$ of $>100 \mu \mathrm{g} / \mathrm{mL}$. Moreover, polysaccharides isolated from fruiting bodies and cultured mycelia of AC inhibited HBV replication activity [16]. After an HBV-producing cell line (MS-G2) was treated with the AC-extracted polysaccharides, antihepatitis B surface antigen (HBsAg) and anti-hepatitis B e antigen ( $\mathrm{HBeAg}$ ) were reduced [16]. Moreover, the ACextracted polysaccharides $(50 \mu \mathrm{g} / \mathrm{mL})$ were found to be more effective than interferon- $\alpha$ (IFN- $\alpha)(1000 \mathrm{U} / \mathrm{mL})$ for HBsAg and HBeAg inhibition [16]. Huang et al. [17] showed that 2,2',5,5' -tetramethoxy-3,4,3',4'-bis(methlylene-dioxy)-6,6' -dimethylbiphenyl $(50 \mu \mathrm{M})$ could suppress the HBsAg and $\mathrm{HBeAg}$ levels in a wild-type HBVproducing cell line (ES2) within a non-toxic range and in a dose-dependent manner. These findings indicate that
AC can effectively attenuate hepatitis virus-induced damage by inhibiting essential viral enzyme activities and antigen production.

\section{Effects on HCC}

\section{Pathogenesis of HCC}

Liver cancer comprises diverse hepatic neoplasms, including HCC, cholangiocarcinoma, hepatoblastoma, and hemangiosarcoma $[18,19]$. Among these, HCC is the primary malignant hepatic cancer worldwide, the fifth most common cancer, and the third leading cause of cancer death around the world [20-22]. The incidence and mortality of HCC are both increasing [23-26]. HCC arises in the context of chronic viral hepatitis (e.g., HBV, HCV, and HDV infection), cirrhosis, alcoholism, toxin or drug poisoning (e.g., aflatoxins), and metabolic disorders (e.g., diabetes, non-alcoholic fatty liver disease, and hereditary diseases) [27]. Recently, geographical differences in HCC incidence have been related to the changing distribution and natural history of HBV and HCV infections [28]. The World Health Organization (WHO) reported that HBV is a human carcinogen, and that an estimated 300400 million individuals are chronically infected with HBV worldwide [29]. Moreover, a large number of carriers fail to eliminate the virus, and progress to chronic viral infection. Continuous hepatic inflammation can lead to chronic hepatitis and cirrhosis. The incidence of HCC in chronically $\mathrm{HBV}$-infected or cirrhotic individuals is 100- and 1000-fold higher, respectively, than in uninfected individuals $[27,30]$. For toxin-induced HCC, ingestion of aflatoxin-B1 (a fungal toxin classified as a type I carcinogen by the International Agency for Research on Cancer (IARC) and produced by the molds Aspergillus flavus and 
Aspergillus parasiticus found in contaminated food) increased the risk of HCC development [31,32]. Aflatoxin$\mathrm{B} 1$ also induced mutations in codon 249 of the $p 53$ tumor suppressor gene and the RAS oncogene [33-36]. Alcohol, which is also classified as a type I carcinogen, is another critical HCC risk factor [31,32]. Alcohol activates monocytes and induces pro-inflammatory cytokine production, and the subsequent increase in endotoxins activates Kupffer cells to release chemokines and cytokines (e.g., tumor necrosis factor (TNF- $\alpha$ ), interleukin-1 $\beta$ (IL-1 $\beta$ ), and interleukin-6 (IL-6)). The resulting oxidative stress activates stellate cells to synthesize large amounts of collagen, leading to fibrosis, cirrhosis, and ultimately HCC [37-39]. Apart from these etiological agents, inflammation, oxidative stress, genetic alternations, activation of oncogenes, inactivation of tumor suppressor genes, genomic instability, and overexpression of growth and angiogenic factors are related to the pathogenesis of $\mathrm{HCC}[31,40]$.

Angiogenesis plays an important role in the pathogenesis (i.e., tumor growth, invasion, and metastasis) of all types of solid tumors, including HCC [41]. As a hypervascular tumor, HCC develops and progresses from a small, avascular, and well-differentiated HCC to a large, highly vascular, and poorly differentiated $\mathrm{HCC}$ within a short period [42]. The expanded endothelium provides a channel for HCC cells to enter the blood circulation system and metastasize to different tissues. During tumor angiogenesis, angiogenic factors (e.g., vascular endothelial cell growth factor (VEGF), fibroblast growth factor-2 (FGF-2), angiogenin, or angiopoietins) and their receptors are produced by tumor cells and endothelial cells (ECs) $[43,44]$. Through VEGF signaling, the most common and potent angiogenic signaling pathway, ECs express VEGF receptors (VEGFR-1 and -2), receive signals from tumor-generated VEGF, proliferate, migrate toward tumor tissues, and form functional neovessels $[43,44]$. Moreover, these angiogenic factors induce gene transcriptional, biochemical, and enzymatic activities, such as extracellular digestion of extracellular matrix by matrix metalloproteinases (MMPs), cell cycle progression, and production of bioactive molecules (e.g., angiogenic factors, cytokines, and chemokines) $[43,44]$. As a result, both tumor cells and ECs are activated in a feedback mechanism, thereby facilitating tumorigenesis [45].

\section{Anti-hepatocarcinoma activity}

Various types of AC extracts and purified components (e.g., antcin $\mathrm{A}, \mathrm{B}$, and $\mathrm{C}$, antroquinonol, methyl antcinate A (MAA), methyl antcinate $B$ (MAB) ethylacetate, and methanolic, ethanolic and fermented extracts) exhibit cytotoxicity through apoptosis in various cancers, especially hepatic carcinoma. Apoptosis is processed sequentially through the activation of death receptors (e.g., Fas receptor) and downstream caspases (e.g., caspase-3, -8, and -9), and mitochondrial function disruption. MAA $(30.2-78 \mu \mathrm{M})$ and antcins $\mathrm{A}$ and $\mathrm{C}(30.2-286.4 \mu \mathrm{M})$ stimulate a series of apoptotic pathway cascades, including caspase-2, -3 , and -9 activation, Bax, Bak, and PUMA protein expression, Bcl-(XL) and Bcl-2 suppression, and cytochrome $\mathrm{c}$ release, resulting in apoptosis [46-48]. MAB and antcin B (100 $\mu \mathrm{M})$-induced apoptosis is characterized by increased DNA fragmentation, cleavage of PARP, sub-G1 population appearance, and chromatin condensation [49]. Moreover, AC components induced NADPH oxidase-provoked oxidative stress $[49,50]$. Another purified AC component, antroquinonol, inhibited HepG2 $\left(\mathrm{IC}_{50}: 0.13 \mu \mathrm{M}\right)$ and Hep3B $\left(\mathrm{IC}_{50}: 4.3 \mu \mathrm{M}\right)$ cell growth [50,51]. Recently, Chiang et al. [52] demonstrated that antroquinonol induced HCC apoptosis through AMPK activation and mTOR translational pathway inhibition, and induced cell cycle arrest through downregulation and suppressed nuclear translocation of cyclin D1, cyclin E, Cdk4, and $\mathrm{Cdk} 2$. An $\mathrm{AC}$ ethyl acetate extract $\left(\mathrm{IC}_{50}: 42.5 \mu \mathrm{g} / \mathrm{mL}\right.$ in HepG2 cells; $78.3 \mu \mathrm{g} / \mathrm{mL}$ in Hep3B cells), methanolic extract $\left(\mathrm{IC}_{50}: 49.5 \mu \mathrm{g} / \mathrm{mL}\right.$ in HepG2 cells; $62.7 \mu \mathrm{g} / \mathrm{mL}$ in Hep3B cells), and ethanolic extract ( $\mathrm{IC}_{50}: 54.2 \mu \mathrm{g} / \mathrm{mL}$ in HepG2 cells; $82.9 \mu \mathrm{g} / \mathrm{mL}$ in Hep3B cells) could also inhibit growth in a similar manner $[4,46,48,53,54]$. Apart from the direct cytotoxicity, cell cycle arrest can be used for controlling tumor growth. During the G1 phase of the cell cycle, the cells increase in size and synthesize essential proteins for the resting steps of the cell division process. It is important to control whether a cell goes into the $S$ phase (DNA synthesis phase) or escapes from the cell cycle. An AC mycelium extract, 4-acetylantroquinonol B (EC $\left.\mathrm{E}_{50}: 0.1 \mu \mathrm{g} / \mathrm{mL}\right)$, induced cell cycle arrest in HepG2 cells, indicating that cells were unable to divide. Western blotting analyses further showed that the protein expressions of different cell cycle-regulating proteins, CDK2 and CDK4, were decreased, while p21, p27, and p53 were increased in HepG2 cells after the AC treatment $[55,56]$. Similar to the case for the conventional anti-cancer drug cisplatin, tumor cell proliferation can be inhibited through induction of DNA damage, cell cycle arrest, and apoptosis. This suppresses the size of tumor tissues, and reduces the chance for subsequent metastasis [57,58].

Anti-angiogenic therapy has been explored as a therapeutic approach to $\mathrm{HCC}[59,60]$. A series of angiogenic inhibitors, e.g., bevacizumab (for blocking the angiogenic factor VEGF), endostatin, IFN- $\alpha$, cyclooxygenase-2 (for inhibiting EC migration, tube formation, proliferation, and angiogenic factor production), interleukin-12 (for producing anti-angiogenic factors), and erlotinib and gefitinib (for inhibiting epidermal growth factor receptor tyrosine kinase activation) are currently in different phases of clinical trials [61].

An AC ethyl acetate extract and AC polysaccharides inhibited angiogenesis in vitro and in vivo. The ethyl acetate 
extract was shown to inhibit cancer invasion of human liver cancer PLC/PRF/5 cells through suppression of angiogenic factor (e.g. VEGF) and extracellular digestive enzyme (e.g. MMP-2 and -9) production, and elevation of enzyme inhibitor (tissue inhibitor of metalloproteinases (TIMP)-1 and TIMP-2) production in the concentration ranges of 10 to $40 \mu \mathrm{g} / \mathrm{mL}$ [47]. These results were confirmed in an animal model by Matrigel plug angiogenesis assays, in which the ethyl acetate extract $(300 \mathrm{mg} / \mathrm{kg}$ ) significantly suppressed tumor growth in nude mice [46]. The VGEF-induced tube formation and migration of ECs, and neovessel formation on chorioallantoic membranes were effectively inhibited by the AC polysaccharide extract $[62,63]$. Cheng et al. [64] demonstrated that the different fractionated AC polysaccharide extracts were able to inhibit VEGF protein expression, binding of VEGF to VEGFR-2, and VEGFR-2 phosphorylation, suggesting that inhibition of VEGF interactions with VEGF receptors is an antiangiogenic mechanism of AC.

Anti-angiogenic therapy is particularly promising, because it is expected to minimize the devastating side effects, such as hair loss, bleeding, and immunosuppression, that are commonly associated with conventional chemotherapy. We previously found that many herbal medicines and natural compounds, such as ginsenosides, indirubin derivatives, and sinomenine, possess anti-angiogenic activities [65-70]. Therefore, AC may also contain anti-angiogenic components.

\section{Effects on alcohol metabolism}

\section{Metabolism of alcohol and its related diseases}

Chronic excessive consumption of alcohol often causes serious health problems, especially to the liver, such as cirrhosis and HCC $[18,71]$. According to the WHO, alcohol is the third largest risk factor for disease worldwide, and has been classified as a type I carcinogen by the IARC [72]. It has been estimated that alcohol leads to 2.5 million deaths each year, and that 320,000 of these deaths are in the age group of 15-29 years, representing $9 \%$ of all deaths in that age group [73]. Alcohol, a watersoluble small molecule, is easily absorbed into the bloodstream from the gastrointestinal tract. It cannot be stored, and is either metabolized or excreted [74,75]. More than $90 \%$ of absorbed alcohol is oxidized by hepatocytes, while the remainder is excreted through pulmonary respiration and urinary excretion $[75,76]$. There are three major pathways for metabolizing alcohol. The primary pathway of alcohol metabolism is the alcohol dehydrogenase (ADH)mediated ethanol oxidation pathway [76,77]. ADH comprises a group of cytosolic enzymes that convert alcohol to acetaldehyde utilizing $\mathrm{NAD}^{+}$as a coenzyme, and the elements of this pathway are mainly located in the liver. At high alcohol concentrations (above $100 \mathrm{mg} / \mathrm{dL}$ ) or during chronic alcohol consumption, the $\mathrm{ADH}$ pathway may become saturated through $\mathrm{NAD}^{+}$depletion. When this happens, the secondary pathway, the microsomal ethanol oxidizing system, is used to break down alcohol [76,77]. In this system, cytochrome P450 enzymes such as CYP2E1, CYP1A2, and CYP2A4 metabolize alcohol to acetaldehyde via $\mathrm{NADPH}$ as a coenzyme instead of $\mathrm{NAD}^{+}[76,78]$. The third pathway is the hydrogen peroxide $\left(\mathrm{H}_{2} \mathrm{O}_{2}\right)$-generating system in peroxisomes [76], which oxidizes alcohol to acetaldehyde and water molecules [75,77]. The acetaldehyde product is further oxidized by aldehyde dehydrogenase (ALDH) to acetate, and subsequently processed in the citric acid cycle. The final products are carbon dioxide, water, and ATP. Through the ADH and ALDH-mediated reactions, $\mathrm{NAD}^{+}$is used up in the form of a coenzyme, and NADH is generated. This increased ratio of NADH: $\mathrm{NAD}^{+}$redox potential in the liver inhibits mitochondrial $\beta$-oxidation of fatty acids and reduces lipid expenditure, resulting in lipogenesis and lipid accumulation in hepatocytes $[79,80]$. The severity of this alcoholic liver disease (ALD) depends on the amount, frequency, and duration of alcohol consumption, and can further develop into more complicated liver damage states, including fibrosis, steatohepatitis, cirrhosis, and cancer [81-83].

\section{Anti-alcoholic activity}

Different types of AC preparations, including ethanolic extracts, aqueous extracts, fermented filtrates, and crude powder, can protect the liver against alcohol damage. Ethanol-induced ALD rats were orally treated with AC ethanolic extracts at a range of $0.25-1.25 \mathrm{~g} / \mathrm{kg}$. Hepatic damage was assessed using serum markers of liver damage, including aspartate aminotransferase (AST), alanine aminotransferase (ALT), and alkaline phosphatase (ALP) [84]. When liver cells are damaged, these enzymes are released into the bloodstream where they can be detected with biochemical or immunological assay kits. The AC extracts could prevent ethanol- and carbon tetrachloride $\left(\mathrm{CCl}_{4}\right)$-induced elevations of the AST, ALT, and ALP levels in the rat blood serum $[85,86]$, indicating that AC conferred protection against chemical-induced liver damage. Moreover, the AC ethanolic extract could normalize the alcohol-induced increase in malondialdehyde, and decreases in glutathione peroxidase, reductase, and glutathione levels in the liver $[86,87]$. In the $\mathrm{CCl}_{4}$-induced ALD model, AC extracts could restore the reduction in the hepatic glutathione content and catalase (CAT) activity, and prevent free radical formation and lipid peroxidation [88]. These in vivo data were validated in a HepG2 cellular model by Kumar et al. [89], who showed that the antroquinonol from the AC ethanolic extract could protect ethanolinduced HepG2 cells against heme oxygenase 1, NF-E2 released factor (Nrf-2), and mitogen-activated protein kinase activation (MAPK). 
An AC fermented filtrate protected HepG2 cells against damage caused by $\mathrm{CCl}_{4}$ [90] and $\mathrm{H}_{2} \mathrm{O}_{2}$ [91]. Song et al. [91] demonstrated that the AC fermented filtrate $(0.05-0.5 \mathrm{mg} /$ $\mathrm{mL}$ ) suppressed lipid peroxidation in $\mathrm{H}_{2} \mathrm{O}_{2}$-induced HepG2 cells. The AC fermented filtrate restored the $\mathrm{CCl}_{4}$-induced increases in ALT, AST, lipid peroxidation, liver lesions, neutrophil infiltration, hydropic swelling, and necrosis, and the reductions in glutathione peroxidase, reductase, and transferase in animal tests [91]. The liver damage caused by chronic alcohol consumption was found to be reduced by an AC crude powder. Chen et al. [85] demonstrated that AC crude powder-treated rats had relatively smaller livers, less lipid accumulation, and lower AST, ALP, and serum alcohol levels. In addition, their serum and hepatic MMP-9 activities, and TNF- $\alpha$, krueppel-like factor6 (KLF-6), and transformation growth factor- $\beta$ (TGF- $\beta$ ) gene expressions were downregulated. Moreover, the AC powder could enhance the metabolism of alcohol by increasing the CAT and ALDH activities [85]. Chen et al. [92] further demonstrated that the $\mathrm{AC}$ crude powder induced downregulation of 3-hydroxy-3-methylglutaryl-CoA reductase, sterol regulatory element-binding protein-1c, acetylCoA carboxylase, fatty acid synthase, and malic gene expression, and upregulation of low-density lipoprotein receptor and peroxisome proliferator-activated alpha gene expression [92]. A dried powder from fermented AC mycelium $(0.34-0.57 \mathrm{~g} / \mathrm{kg})$ could protect the rat liver against damage from alcohol, and significantly suppress the alcohol-induced increases in glutamate-pyruvate aminotransferase, glutamate-oxaloacetate aminotransferase, superoxide dismutase, and CAT activities. Histological data validated the AC protective effects by showing a reduction in alcohol-induced lipid vacuole accumulation, and hydropic degradation of hepatocytes [93].

\section{Conclusions}

Hepatoprotective activities, including anti-hepatitis, antihepatocarcinoma, and anti-alcoholism, of AC have been demonstrated in vitro and in vivo. However, many of the underlying mechanistic actions, such as the pharmacokinetics and pharmacodynamics, remain unclear. Furthermore, human and clinical trials are required for a full evaluation of this valuable medicinal mushroom for potential clinical applications.

\footnotetext{
Abbreviations

AC: Antrodia cinnamomea; FDA: Food and Drug Administration HAV: Hepatitis A virus; HBV: Hepatitis B virus; HCV: Hepatitis C virus; HDV: Hepatitis D virus; HCC: Hepatocellular carcinoma; HBsAg: Hepatitis B surface antigen; HBeAg: Hepatitis B e antigen; IFN-a: Interferon-a; WHO: World Health Organization; IARC: International Agency for Research on Cancer; TNF-a: Tumor necrosis factor; IL-1B: Interleukin-1B; IL-6: Interleukin-6; VEGF: Vascular endothelial cell growth factor; FGF-2: Fibroblast growth factor-2; EC: Endothelial cell; VEGFR-1: VEGF receptor 1; VEGFR-2: VEGF receptor 2; MMP: Matrix metalloproteinase; MAA: Methyl antcinate A; MAB: Methyl antcinate B; TIMP-1: Tissue inhibitor of metalloproteinases-1; TIMP-2: Tissue inhibitor of metalloproteinases-2; ADH: Alcohol
}

dehydrogenase; $\mathrm{H}_{2} \mathrm{O}_{2}$ : Hydrogen peroxide; ALDH: Aldehyde dehydrogenase; ALD: Alcoholic liver disease; AST: Aspartate aminotransferase; ALT: Alanine aminotransferase; ALP: Alkaline phosphatase; $\mathrm{CCl}_{4}$ : Carbon tetrachloride; CAT: Catalase; Nrf-2: NF-E2 released factor; MAPK: Mitogen-activated protein kinase activation; ALDH: Aldehyde dehydrogenase.

\section{Competing interests}

The authors declare that they have no competing interest.

\section{Authors' contributions}

PYKY was responsible for drafting and proofreading of this article. The information searching was done by YYW, KYKW, and YKT. Final proofreading was done by KSYL. All authors read and approved the final manuscript.

\section{Acknowledgments}

K.S.Y. Leung would like to thank the Hong Kong Baptist University for financial support. The generous support of GeneFerm Biotechnology Company Limited of Taiwan for the entire research on Antrodia cinnamomea is gratefully acknowledged.

Received: 8 May 2013 Accepted: 23 October 2013

Published: 1 November 2013

\section{References}

1. Chen CJ, Su CH, Lan MH: Study on solid cultivation and bioactivity of Antrodia camphortaa. Fungal Sci 2001, 16:65-72.

2. Zang M, Su CH: Ganoderma comphoratum, a new taxon in genus Ganderma from Taiwan, China. Acta Bot Yunnanica 1990, 12:395-396.

3. Phuong do T, Ma CM, Hattori M, Jin JS: Inhibitory effects of antrodins A-E from Antrodia cinnamomea and their metabolites on hepatitis $C$ virus protease. Phytother Res 2009, 23:582-584.

4. Chen YS, Pan JH, Chiang BH, Lu FJ, Sheen LY: Ethanolic extracts of Antrodia cinnamomea mycelia fermented at varied times and scales have differential effects on hepatoma cells and normal primary hepatocytes. J Food Sci 2008, 73:H179-H185.

5. Ryder SD, Beckingham IJ: ABC of diseases of liver, pancreas, and biliary system: acute hepatitis. BMJ 2001, 322:151-153.

6. Matheny SC, Kingery JE: Hepatitis A. Am Fam Physician 2012, 86:1027-1034.

7. Conjeevaram HS, Lok AS: Management of chronic hepatitis B. $J$ Hepatol 2003, 38:S90-S103.

8. Perrillo RP: Management of the patient with hepatitis B virus-related cirrhosis. J Hepatol 2003, 39:S177-S180.

9. Chisari FV: Rous-Whipple award lecture. Viruses, immunity, and cancer: lessons from hepatitis B. Am J Pathol 2000, 156:1117-1132.

10. Mulkay JP: Hepatitis B: screening and treatment. Rev Med Brux 2012, 33:215-222.

11. Peppa D, Maini MK: Pathogenesis of hepatitis B virus infection and potential for new therapies. Br J Hosp Med (Lond) 2012, 73:581-584.

12. Cohen J: Report of new hepatitis virus has researchers intrigued and upset. Science 1999, 285:644-645.

13. Cohen J: The scientific challenge of hepatitis C. Science 1999, 285:26-30

14. Terilli RR, Cox AL: Immunity and hepatitis C: a review. Curr HIV/AIDS Rep 2013, 10:51-58.

15. Bouchard MJ, Navas-Martin S: Hepatitis B and C virus hepatocarcinogenesis: lessons learned and future challenges. Cancer Lett 2011, 305:123-143.

16. Lee IH, Huang RL, Chen CT, Chen HC, Hsu WC, Lu MK: Antrodia camphorata polysaccharides exhibit anti-hepatitis B virus effects. FEMS Microbiol Lett 2002, 209:63-67.

17. Huang RL, Huang QL, Chen CF, Chang TT, Chou CJ: Anti-viral effects of active compounds from Antrodia camphorata on wild-type and lamivudine-resistant mutant HBV. Chin Pharmaceut J 2003, 55:371-379.

18. Popper $H$, Thung SN, Gerber MA: Pathology of alcoholic liver diseases. Semin Liver Dis 1981, 1:203-216.

19. Schaff Z, Székely E, Járay B, Kiss A: Pathology of liver tumors. Orv Hetil 2004, 145:368-374.

20. Parkin DM, Bray F, Ferlay J, Pisani P: Estimating the world cancer burden globocan 2000. Int J Canc 2001, 94:153-156.

21. Parkin DM, Bray FI, Devesa SS: Cancer burden in the year 2000. The global picture. Eur J Canc 2001, 37:S4-S66. 
22. Chen JG, Zhu J, Parkin DM, Zhang YH, Lu JH, Zhu YR, Chen TY: Trends in the incidence of cancer in Qidong, China. 1978-2002. Int J Canc 2006, 119:1447-1454.

23. Deuffic S, Poynard T, Buffat L, Valleron AJ: Trends in primary liver cancer. Lancet 1998, 351:214-215.

24. El-Serag HB, Mason AC: Rising incidence of hepatocellular carcinoma in the United States. N Engl J Med 1999, 340:745-750.

25. El-Serag HB, Davila JA, Petersen NJ, McGlynn KA: The continuing increase in the incidence of hepatocellular carcinoma in the United States: an update. Ann Intern Med 2003, 139:817-823.

26. Taylor-Robinson SD, Foster GR, Arora S, Hargreaves S, Thomas HC: Increase in primary liver cancer in the UK, 1979-94. Lancet 1997, 350:1142-1143.

27. Wong $\mathrm{CM}, \mathrm{Ng} \mathrm{IO}$ : Molecular pathogenesis of hepatocellular carcinoma. Liver Int 2008, 28:160-174.

28. Idilman R, De Maria N, Colantoni A, Van Thiel DH: Pathogenesis of hepatitis B and C-induced hepatocellular carcinoma. J Viral Hepat 1998, 5:285-299.

29. WHO: Surveillance and response: WHO. Hepatitis B, Department of communable diseases. 2002.

30. Moradpour D, Blum HE: Pathogenesis of hepatocellular carcinoma. Eur J Gastroenterol Hepatol 2005, 17:477-483.

31. Gomaa Al, Khan SA, Toledano MB, Waked SD: Taylor-Robinson, hepatocellular carcinoma: epidemiology, risk factors and pathogenesis. World J Gastroenterol 2008, 14:4300-4308.

32. Farazi PA, DePinho RA: Hepatocellular carcinoma pathogenesis: from genes to environment. Nat Rev Canc 2006, 6:674-687.

33. Bressac B, Kew M, Wands J, Ozturk M: Selective G to T mutations of p53 gene in hepatocellular carcinoma from southern Africa. Nature 1991, 350:429-431.

34. Riley J, Mandel HG, Sinha S, Judah DJ, Neal GE: In vitro activation of the human Harvey-ras proto-oncogene by aflatoxin B1. Carcinogenesis 1997, 18:905-910.

35. Aguilar F, Harris CC, Sun T, Hollstein M, Cerutti P: Geographic variation of p53 mutational profile in nonmalignant human liver. Science 1994, 264:1317-1319.

36. Ozturk M: p53 mutation in hepatocellular carcinoma after aflatoxin exposure. Lancet 1991, 338:1356-1359.

37. Hoek JB, Pastorino JG: Ethanol, oxidative stress, and cytokine-induced liver cell injury. Alcohol 2002, 27:63-68.

38. McClain CJ, Hill DB, Song Z, Deaciuc I, Barve S: Monocyte activation in alcoholic liver disease. Alcohol 2002, 27:53-61.

39. Campbell JS, Hughes SD, Gilbertson DG, Palmer TE, Holdren MS, Haran AC, Odell MM, Bauer RL, Ren HP, Haugen HS, Yeh MM, Fausto N: Platelet-derived growth factor $C$ induces liver fibrosis, steatosis, and hepatocellular carcinoma. Proc Natl Acad Sci USA 2005, 102:3389-3394.

40. Parikh S, Hyman D: Hepatocellular cancer: a guide for the internist. Am J Med 2007, 120:194-202.

41. Ribatti D, Vacca A, Dammacco F: The role of the vascular phase in solid tumor growth: a historical review. Neoplasia 1999, 1:293-302.

42. Semela D, Dufour JF: Angiogenesis and hepatocellular carcinoma. J Hepatol 2004, 41:864-880.

43. Bergers $\mathrm{G}$, Benjamin LE: Tumorigenesis and the angiogenic switch. Nat Rev Canc 2003, 3:401-410.

44. Carmeliet $P$, Jain RK: Angiogenesis in cancer and other diseases. Nature 2000, 407:249-257.

45. Sugimachi K, Tanaka S, Terashi T, Taguchi K, Rikimaru T, Sugimachi K: The mechanisms of angiogenesis in hepatocellular carcinoma: angiogenic switch during tumor progression. Surgery 2002, 131:S135-S141.

46. Hsu YL, Kuo YC, Kuo PL, Ng LT, Kuo YH, Lin CC: Apoptotic effects of extract from Antrodia camphorata fruiting bodies in human hepatocellular carcinoma cell lines. Canc Lett 2005, 221:77-89.

47. Hsu YL, Kuo PL, Cho CY, Ni WC, Tzeng TF, Ng LT, Kuo YH, Lin CC: Antrodia cinnamomea fruiting bodies extract suppresses the invasive potential of human liver cancer cell line PLC/PRF/5 through inhibition of nuclear factor kappaB pathway. Food Chem Toxicol 2007, 45:1249-1257.

48. Kuo PL, Hsu YL, Cho CY, Ng LT, Kuo YH, Lin CC: Apoptotic effects of Antrodia cinnamomea fruiting bodies extract are mediated through calcium and calpain-dependent pathways in Hep 3B cells. Food Chem Toxicol 2006, 44:1316-1326.

49. Hsieh YC, Rao YK, Whang-Peng J, Huang CY, Shyue SK, Hsu SL, Tzeng YM: Antcin $B$ and its ester derivative from Antrodia camphorata induce apoptosis in hepatocellular carcinoma cells involves enhancing oxidative stress coincident with activation of intrinsic and extrinsic apoptotic pathway. J Agric Food Chem 2011, 59:10943-110954.

50. Hsieh YC, Rao YK, Wu CC, Huang CY, Geethangili M, Hsu SL, Tzeng YM: Methyl antcinate A from Antrodia camphorata induces apoptosis in human liver cancer cells through oxidant-mediated cofilin- and Bax-triggered mitochondrial pathway. Chem Res Toxicol 2010, 23:1256-1267.

51. Lee TH, Lee CK, Tsou WL, Liu SY, Kuo MT, Wen WC: A new cytotoxic agent from solid-state fermented mycelium of Antrodia camphorate. Planta Med 2007, 73:1412-1415.

52. Chiang PC, Lin SC, Pan SL, Kuo CH, Tsai IL, Kuo MT, Wen WC, Chen P, Guh JH: Antroquinonol displays anticancer potential against human hepatocellular carcinoma cells: a crucial role of AMPK and mTOR pathways. Biochem Pharmacol 2010, 79:162-171.

53. Song TY, Hsu SL, Yen GC: Induction of apoptosis in human hepatoma cells by mycelia of Antrodia camphorata in submerged culture. J Ethnopharmacol 2005, 100:158-167.

54. Song TY, Hsu SL, Yeh CT, Yen GC: Mycelia from Antrodia camphorata in Submerged culture induce apoptosis of human hepatoma HepG2 cells possibly through regulation of Fas pathway. J Agric Food Chem 2005, 53:5559-5564

55. Lin YW, Chiang BH: 4-acetylantroquinonol B isolated from Antrodia cinnamomea arrests proliferation of human hepatocellular carcinoma HepG2 cell by affecting p53, p21 and p27 levels. J Agric Food Chem 2011, 59:8625-8631.

56. Lin $\mathrm{XW}$, Pan JH, Liu RH, Kuo YH, Sheen LY, Chiang BH: The 4-acetylantroquinonol $\mathrm{B}$ isolated from mycelium of Antrodia cinnamomea inhibits proliferation of hepatoma cells. J Sci Food Agric 2010, 90:1739-1744.

57. Cepeda V, Fuertes MA, Castilla J, Alonso C, Quevedo C, Pérez JM: Biochemical mechanisms of cisplatin cytotoxicity. Anticancer Agents Med Chem 2007, 7:3-18.

58. Jordan P, Carmo-Fonseca M: Molecular mechanisms involved in cisplatin cytotoxicity. Cell Mol Life Sci 2000, 57:1229-1235.

59. Ribatti D, Vacca A, Nico B, Sansonno D, Dammacco F: Angiogenesis and anti-angiogenesis in hepatocellular carcinoma. Canc Treat Rev 2006, 32:437-444

60. Pang R, Poon RT: Angiogenesis and antiangiogenic therapy in hepatocellular carcinoma. Canc Lett 2006, 242:151-167.

61. Finn RS, Zhu AX: Targeting angiogenesis in hepatocellular carcinoma: focus on VEGF and bevacizumab. Expert Rev Anticancer Ther 2009, 9:503-509.

62. Chen SC, Lu MK, Cheng JJ, Wang DL: Antiangiogenic activities of polysaccharides isolated from medicinal fungi. FEMS Microbiol Lett 2005, 249:247-254.

63. Yang CM, Zhou YJ, Wang RJ, Hu ML: Anti-angiogenic effects and mechanisms of polysaccharides from Antrodia cinnamomea with different molecular weights. J Ethnopharmacol 2009, 123:407-412.

64. Cheng JJ, Huang NK, Chang TT, Wang DL, Lu MK: Study for anti-angiogenic activities of polysaccharides isolated from Antrodia cinnamomea in endothelial cells. Life Sci 2005, 76:3029-3042.

65. Chan YK, Kwok HH, Chan LS, Leung KS, Shi J, Mak NK, Wong RN, Yue PY: An indirubin derivative, E804, exhibits potent angiosuppressive activity. Biochem Pharmacol 2012, 83:598-607.

66. Yue PY, Mak NK, Cheng YK, Leung KW, Ng TB, Fan DT, Yeung HW, Wong RN: Pharmacogenomics and the Yin/Yang actions of ginseng: anti-tumor, angiomodulating and steroid-like activities of ginsenosides. Chin Med 2007, 2:42-62.

67. Leung KW, Yung KK, Mak NK, Yue PY, Luo HB, Cheng YK, Fan TP, Yeung HW, $\mathrm{Ng} \mathrm{TB}$, Wong RN: Angiomodulatory and neurological effects of ginsenosides. Curr Med Chem 2007, 14:1371-1380.

68. Yue PY, Wong DY, Wu PK, Leung PY, Mak NK, Yeung HW, Liu L, Cai Z, Jiang ZH, Fan TP, Wong RN: The angiosuppressive effects of 20(R)-ginsenoside Rg3. Biochem Pharmacol 2006, 72:437-445.

69. Fan TP, Yeh JC, Leung KW, Yue PY, Wong RN: Angiogenesis: from plants to blood vessels. Trends Pharmacol Sci 2006, 27:297-309.

70. Kok TW, Yue PY, Mak NK, Fan TP, Liu L, Wong RN: The anti-angiogenic effect of sinomenine. Angiogenesis 2005, 8:3-12

71. Charels K, Klöppel G: Pathology and pathogenesis of toxic (alcoholic) liver disease. Hepatogastroenterology 1991, 38:189-194.

72. IARC Working Group on the Evaluation of Carcinogenic Risks to Humans: Personal habits and indoor combustions. Volume $100 \mathrm{E}$. A review of human carcinogens. IARC Monogr Eval Carcinog Risks Hum 2012, 100:1-538.

73. Yip WW, Burt AD: Alcoholic liver disease. Semin Diagn Pathol 2006, 23:149-160 
74. Doria JJ: Alcohol metabolism. Alcohol Health Res World 1997, 21:323.

75. Bode C, Bode JC: Alcohol absorption, metabolism, and production in the gastrointestinal tract. Alcohol Health Res World 1997, 21:82-83.

76. Zakhari S: Overview: How is alcohol metabolized by the body? Alcohol Res Health 2006, 29:245-254.

77. Lieber CS: Hepatic, metabolic and toxic effects of ethanol: 1991 update. Alcohol Clin Exp Res 1991, 15:573-592.

78. Lieber C: The discovery of the microsomal ethanol oxidizing system and its physiologic and pathologic role. Drug Metab Rev 2004, 36:511-529.

79. Donohue TM: Alcohol-induced steatosis in liver cells. World J Gastroenterol 2007, 13:4974-4978.

80. Sozio M, Crabb DW: Alcohol and lipid metabolism. Am J Physiol Endocrinol Metab 2008, 295:E10-E16.

81. Bruha R, Dvorak K, Petrtyl J: Alcoholic liver disease. World J Hepatol 2012, 4:81-90.

82. Syn WK, Teaberry V, Choi SS, Diehl AM: Similarity and differences in the pathogenesis of alcoholic and non-alcoholic steatohepatiotis. Semin Liver Dis 2009, 29:200-210.

83. Fernández-Checa JC, Kaplowitz N, Colell A, García-Ruiz C: Oxidative stress and alcoholic liver disease. Alcohol Health Res World 1997, 21:321-324.

84. Lieber CS: Alcohol, liver, and nutrition. J Am Coll Nutr 1991, 10:602-632.

85. Wu MT, Tzang BS, Chang YY, Chiu CH, Kang WY, Huang CH, Chen YC: Effects of Antrodia camphorata on alcohol clearance and antifibrosis in livers of rats continuously fed alcohol. J Agric Food Chem 2011, 59:4248-4254.

86. Lu ZM, Tao WY, Zou XL, Fu HZ, Ao ZH: Protective effects of mycelia of Antrodia camphorata and Armillariella tabescens in submerged culture against ethanol-induced hepatic toxicity in rats. J Ethnopharmacol 2007, 110:160-164.

87. Lu ZM, Tao WY, Xu HY, Ao ZH, Zhang XM, Xu ZH: Further studies on the hepatoprotective effect of Antrodia camphorata in submerged culture on ethanol-induced acute liver injury in rats. Nat Prod Res 2011, 25:684-695.

88. Hsiao G, Shen MY, Lin KH, Lan MH, Wu LY, Chou DS, Lin CH, Su CH, Sheu JR: Antioxidative and hepatoprotective effects of Antrodia camphorata extract. J Agric Food Chem 2003, 51:3302-3308.

89. Kumar KJ, Chu FH, Hsieh HW, Liao JW, Li WH, Lin JC, Shaw JF, Wang SY: Antroquinonol from ethanolic extract of mycelium of Antrodia cinnamomea protects hepatic cells from ethanol-induced oxidative stress through Nrf-2 activation. J Ethnopharmacol 2011, 136:168-177.

90. Lin WC, Kuo SC, Lin WL, Fang HL, Wang BC: Filtrate of fermented mycelia from Antrodia camphorata reduces liver fibrosis induced by carbon tetrachloride in rats. World J Gastroenterol 2006, 12:2369-2374.

91. Song TY, Yen GC: Protective effects of fermented filtrate from Antrodia camphorata in submerged culture against $\mathrm{CCl} 4$-induced hepatic toxicity in rats. J Agric Food Chem 2003, 51:1571-1577.

92. Huang $\mathrm{CH}$, Chang YY, Liu CW, Kang WY, Lin YL, Chang HC, Chen YC: Fruiting body of Niuchangchih (Antrodia camphorata) protects livers against chronic alcohol consumption damage. J Agric Food Chem 2010, 58:3859-3866.

93. Dai YY, Chuang CH, Tsai CC, Sio HM, Huang SC, Chen JC, Hu ML: The proliferation of Anthrodia camphorate against acute hepatotoxicity of alcohol in rat. J Food Drug Ann 2003, 11:177-185.

doi:10.1186/1749-8546-8-21

Cite this article as: Yue et al:: Current evidence for the hepatoprotective activities of the medicinal mushroom Antrodia cinnamomea. Chinese Medicine 2013 8:21.

\section{Submit your next manuscript to BioMed Central and take full advantage of:}

- Convenient online submission

- Thorough peer review

- No space constraints or color figure charges

- Immediate publication on acceptance

- Inclusion in PubMed, CAS, Scopus and Google Scholar

- Research which is freely available for redistribution 